\title{
BRÖGGER IN STOCKHOLM 1881-1890, A SEMINAL PERIOD OF NORDIC GEOLOGY
}

\author{
FRANS E. WICKMAN
}

\begin{abstract}
WICKMAN, FRANS E., 1986: Brögger in Stockholm 1881-1890, a seminal period of Nordic geology. Bull. Geol. Soc. Finland 58, Part 1, 29-44.

W. C. Brögger was Professor of Geology and Mineralogy at the new Stockholm University in the period 1881-1890. Among his students during this period were V. Ussing from Denmark, W. Ramsay and J. J. Sederholm from Finland, J. H. L. Vogt from Norway and H. Bäckström, G. Flink and A. Hamberg from Sweden. This group is discussed mainly using the correspondence between Brögger, Ramsay, Sederholm and Bäckström. The early scientific development of Sederholm is especially considered.
\end{abstract}

Frans E. Wickman: Department of Geology, University of Stockholm, S-10691 Stockholm, Sweden.

\section{Introduction}

In 1869 an association was formed in Stockholm, Sweden with the sole purpose of founding a private university in the city. The association found it difficult to raise enough funds, it was not until 1878 that lectures in some of the natural sciences could be given. The official name was Stockholms Högskola (Stockholm University, it will often here be shortened SU). In 1881 its Board of Trustees was able to appoint two professors and some temporary teachers in other subjects.

One of the two professorships was in 'geology and mineralogy' and the Board selected the Norwegian Waldemar Christopher Brögger from Kristiania (Oslo). Since the Board had no special competence in natural sciences, it had appointed a special committee, '7-mannanämnden' (the 7 man committee) to advise the Board. It consisted of professors from other learned institutions in Stockholm.

In the case of Brögger, who was then 30 years old, the committee had had five distinguished geologists to evaluate him and his work, all of whom recommended him. In their letter to the Board the committee also reported:

». . . since in addition several distinguished geologists and mineralogists, who have been consulted, stated firstly that Brögger is not only fully competent to the named position, but also incomparably the most suitable of all geologists in Scandinavia, and secondly that his appointment at the university would be of exceptionally great benefit for the university and for the study of geology in our country, . ..» (Minutes of the Board of Trustees June 11, 1881, transl.fr. Swed.).

Even if, perhaps, the number of suitable men in 1881 was not very great the praise for this young man is remarkable. The Board appointed him Professor of Geology and Mineralogy at the University from Dec. 1, 1881. 


\section{The background of Brögger}

Brögger (1851-1940) was born in Oslo, Norway. In 1870 he started his university studies at Oslo as a zoology student but soon changed to the field of geology.

Few universities in the world have a better location than Oslo from the point of view of a geoscientist: in the middle of a Permian rift valley with a remarkable variety of igneous, sedimentary and metamorphic rocks. The Paleozoic sedimentary rocks are rich in fossils and the metamorphic ones show beautiful examples of contact metamorphism. Quaternary deposits and features from the Last Glaciation are well developed in the area. The Caledonian mountains and the Proterozoic rocks of southern Norway are not far away.

The possibilities to develop scientifically were also good in other ways for the highly gifted and super-energetic student. His professor, Theodor Kjerulf, was a distinguished geologist who had studied in Germany in the 1850's. Most importantly in 1876 Brögger became assistent in the mineral collection of the University and could go to Germany and France in 1877 - 78 on a grant. He studied modern methods in mineralogy and petrography with some of the most distinguished scientists of the time. Particularly important for the future was his stay in Strassburg, Germany where, shortly before, the university had obtained many young remarkable professors. Brögger stayed with Paul von Groth, the mineralogist and crystallographer, and Harry Rosenbusch, the petrographer, and formed life-long friendships with them. In 1878 he became a 'stipendiat' (research associate) at the University.

His scientific work during the 1870's was mainly paleontological and mineralogical. Thanks to his early study of zoology he could describe the fossils of some of the strata in the Oslo field, and his work in certain portions of the Cambrian system was pioneering. His mineralogical work was very good for its time, but his major work was »Die silurischen Etagen 2 und 3 im Kristia- niagebiet und auf Eker, ihre Gliederung, Fossilien, Schichtstörungen und Contactmetamorphosen», which was not printed until 1882, when he was already in Stockholm. It was a remarkable feat, describing the rocks from every aspect, giving details about paleontology, tectonics and petrography, both igneous and metamorphic.

\section{Stockholm University and its Department of Geology and Mineralogy}

The new university was of an unusual kind: it did not intend to be a place where students studied for degrees, those who wanted or needed a degree had to go to a state university for the examinations. Instead the new university promoted research and advanced teaching, and was therefore more like an Institute of Advanced Studies. But it also gave popular but scientifically correct lectures to the general public. From its history (Bedoire and Thullberg 1978) it can be seen that the annual total number of students in the 1880's was very small, between 30 and 50 .

When Brögger was appointed, a Department of Geology and Mineralogy did not exist. The Board had obtained an apartment of seven empty rooms of varying sizes, which had been placed at the disposal of the university by the City of Stockholm.

His first problem was therefore to bring together instruments, collections of rocks and minerals and a library. The economic situation of SU was weak. Brögger therefore had to find private sources to a great extent. Fortunately it turned out that he had a natural gift to find donators, a gift that later in Norway he could use for a variety of purposes.

$\mathrm{He}$ received not only money but also gifts in the form of periodicals and collections of rocks and minerals. Particularly helpful was his personal connections with the Norwegian cabinet minister H. R. Astrup, who was a millionaire. Brögger therefore could write to his mother on New Years Day 1883: 


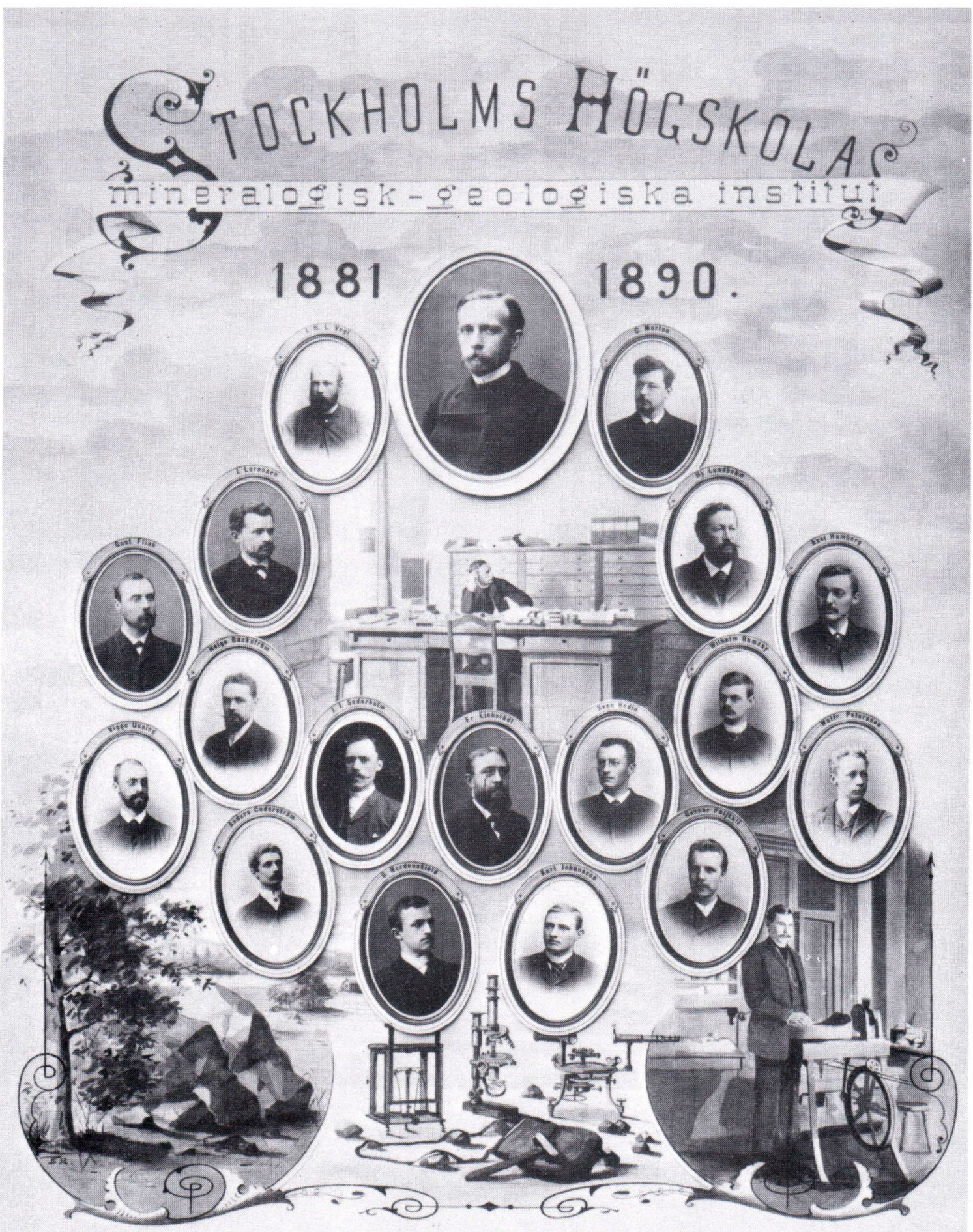

Fig. 1. Picture given to Brögger in January 1891 by his former students in Stockholm. 
"All rooms are certainly small, but I have utilized the space well. I have already a rather good library, as well as the best collection of instruments in Norden, only behind those of the larger German universities. But students are still scarce, but they will surely come by and by» (transl. fr. Norweg.).

His first lecture at the university was given on Feb. 1, 1882 (in Norweg.) with the title »The importance of crystallography for modern petrography and thereby for geology", certainly a topic that a young, bright professor also could choose today more than a century later.

In 1886 Brögger was offered the professorship in geology and mineralogy at Uppsala University, but stayed in Stockholm because his position was more free and because he had obtained a large grant from Astrup for his work in Stockholm. Kjerulf died in 1888 and at the end of 1890 Brögger returned to Oslo to become his successor.

It should be mentioned that Brögger early obtained a special technician for making thin sections, who became not only skilled but a real master in his art, A. Andersson. Those students who later studied with Rosenbusch complained that they got 'thick sections' not thin sections like in Stockholm.

\section{Brögger's students in Stockholm}

Brögger's hope in the letter to his mother that he would get students was fulfilled, and among them we find some of the great names in the geosciences of the Nordic countries.

The students are shown in Fig. 1, a picture which was presented to Brögger when he moved back to Oslo. The picture hung in his study in his Oslo home until his death (Quensel 1940). Since the students represented all the then Nordic countries and since a long time has passed and their futures differed greatly, it is convenient to present short biographic notes of them and some other geologists in Appendix 1.

A persual of it shows that some students left geology early for various reasons (death, other kinds of job etc.); in this category we have Cederström, Eichstädt, Lorenzen, Morton, Nor- denskiöld, and Paikull. Some went to applied geology: Johansson and Lundbohm. A unique case is Sven Hedin, who without really being a scientist nevertheless contributed to the development of science by his expeditions in Central Asia. Most of the others became university professors or the like: Bäckström and Petersson in Stockholm, Hamberg in Uppsala, Ramsay and Sederholm in Helsinki, Ussing in Copenhagen and Vogt in Oslo and Trondheim. Finally we have the superb mineral collector Flink and the geologist Svenonius (missing on the picture), who both worked in governmental positions in science.

Looking into the correspondence between all these persons it is evident that the letters by Sederholm, Ramsay and, to some extent, Bäckström are the most interesting ones, because Ramsay and Sederholm were very close friends and exchanged many letters before 1910. Bäckström was a witty but infrequent letter writer. Brögger was mostly a recipient of information. Ussing was very careful in his letter writing and his letters are not very informative about his feelings. It appears that his most interesting letters are written to his father, J. L. Ussing. Vogt rarely discussed anything but scientific matters.

The following is therefore to a large extent based on the correspondence between Ramsay and Sederholm and their correspondence with Brögger and Bäckström.

\section{Brögger in the eyes of his students}

Brögger had a complex personality and therefore the opinions of his closer students changed as they got to know him better. I shall try to illustrate this point.

During their stay with him the students could observe many of his great traits, such as his high intelligence, his great ability as a teacher and scientific inspirer. He was super-energetic and got results not only in his scientific work but also in almost every other question he was interested in, for example the success of his own students. 
We must also remember that this was a time when petrography was a young science, still in its pioneering stage and Brögger and his pupils felt that they were at the scientific forefront, fighting against obscurants of all kinds, but particularly against conservative geologists in the Nordic countries. In addition the students were young men of the 1880's, that is believing in rationality, in progress, science and technology.

Brögger was their leader but he was also thought of as a fatherly figure, who could be relied upon and give help in difficult situations. All this is well illustrated in a letter by the then 25 year old Sederholm, written in May 1888, when he had returned to Finland after his stay with Brögger. He was then just newly employed by the Survey in Finland. This long letter in Swedish is of great interest for many questions, a complete translation is therefore given in Appendix 2.

The letter is a rather strange mixture of admiration, almost filial piety, and shrewed diplomacy of the 'carrot and stick' type. We shall return several times to it.

Sederholm's concern in this letter about the health of Brögger was genuine, he returns to this question and on May 30, 1891 he writes for example:

»When I think about how you imperil your [health] I easily adopt a sermonizing tone, which perhaps is improper but which depends upon the fact that we, your pupils, think we in a way have some share in you ....».

The background is that Brögger many times did overwork himself and had to suffer for it, but he by far outlived all his Stockholm students, except Hedin.

For a person with Sederholm's gifts it is obvious that he should soon be aware of the many different sides of Brögger's character. This can be seen in a letter to Ramsay where he is discussing Rosenbusch and Brögger (Feb. 21, 1891):

\footnotetext{
»Basically it is a matter of taste, but personally I must confess that I can more easily understand Brögger's uncompromising work for himself and his own aims, as long as there is a idealistic purpose behind it, than these petty aspirations»".
}

And on Oct. 30, 1896 Sederholm wrote from Oslo:

»It appears that he [Brögger] fitted much better to the life in Stockholm than in Kristiania [Oslo] where all his petty traits of character display themselves while the great ones do not appear and are also not paid attention to".

Since Ramsay and Sederholm were quite frank to each other any difference in opinion would have resulted in a strong answer. I have found none.

\section{Foreign studies of the students}

It appears that before the First World War most promising students travelled around Europe on some sort of journeyman's Wanderjahr. A number of Brögger's students made such a trip. Among the possible professors they selected firstly the two friends of Brögger: Rosenbusch and Groth, particularly Rosenbusch. A few, Bäckström, Ramsay and Sederholm also went to Paris to study under Fouqué and Michel-Levy, but none went to Great Britain or Russia. The students exchanged letters about their experiences but also told Brögger to some extent. They all agree that the teaching in Stockholm was as thorough and qualitatively as good or better than what they got on the Continent. However some subject matter was not studied in Norden.

Even if we must remember that "no man is a hero in the eyes of his valet» it is of great interest to have their views of for example Rosenbusch. In a letter to Brögger (Feb. 20, 1891) Bäckström wrote that Sederholm thought that Rosenbusch was too theoretical and had seen much less in nature than Brögger. This rather neutral statement was transformed into a frank letter the next day from Sederholm to Ramsay where he related his discussions with Rosenbusch about the rapakivi problems:

»During all these discussions I have also had opportunity to make several psychological observations, which together with Osann's stories have substantially changed my opinion about Rosenbusch.

It is certain that he is not such an »einfacher Biedermann» 
[simple John Doe] whom he seems to be on first acquaintance, and above all, it is certain that he is not so free from conceit and ambition as he tries to suggest in his small autobiographic stories.

I have not yet discussed one question with him without that he in the first place has put such matters which make him and his opinions important, and in the second place to help his listeners to a correct understanding. In fact, many times I have had the same experience as Osann that his argumentation then is straight quibbling.»

and somewhat later about the crystallization of rapakivi granite:

»If he then rounds off by saying 'jeder verständige Petrograph wurde dieses als Idiomorphie des Feldspathes deuten' [every competent petrographer will interprete this as feldspar idiomorphism] or something similar and I then show it [the thin section] to Osann or sometimes Sauer, so, I will be bound, their interpretation is always straight opposite to those of Rosenbusch. Thus neither they nor I are 'verständige Petrographen', since we conclude the law from the observations rather than correcting our observations to fit the law.»

and finally

»Der Geheimrath ist ein vollendeter Schauspieler [The 'Geheimrath' is a perfect actor] he [Osann] says and of this I have at least seen the most magnificent examples.»

This is not the result of the attitude of Sederholm, because Bäckström in a letter to Sederholm says (Oct. 11, 1891):

"Your opinion about Rosenbusch is correct. He is always certain that he is right and definite, but if one happens to remember what he has said earlier, one will discover contradictions, and this is sad because it decreases the confidence one otherwise would have in him to a much higher degree.»

In the following of this letter Bäckström writes about a visit to Leipzig where he met Zirkel and he makes some comparisons:

»Zirkel was very knowledgeable about the literature and talked much about the large petrography he will start printing after Christmas, but I understood perfectly well why he has been surpassed by Rosenbusch: partly Zirkel is an easy-going fellow, partly he always considers matters to such a degree from both sides that his power of action is crippled. He is never so positive as Rosenbusch, and it is probably this fact which is the greatness of Rosenbusch, both as a synthesizing scientist and as a teacher, also Zirkel has not had any better students in later years.»

The other students who were studying with Rosenbusch do not give such open opinions. Ussing, for example, who was both with Groth and Rosenbusch, did not discuss such matters in his letters. This is not surprising since his biographers describe him as silent and careful.

The few who went to Paris appear to be very satisfied, but I will only quote one sentence from a letter of Bäckström to Ramsay (Nov. 15, 1892):

») Tell Sederholm that France is the cradle of the theory of 'gneiss formed by granite enema'».

\section{Events around Brögger's return to Oslo}

When Brögger came to Stockholm he soon experienced the difficulties as a foreigner to be accepted. He worked almost exclusively with Norwegian problems, and his masterpiece, the whole volume 16 of Z. Kryst., was published in 1890 and was devoted to the syenite pegmatites of Southern Norway. This work established him as a recognized world leader in his field. It is this work Sederholm is thinking about when he talks about overwork (p. 43-44).

Even if Brögger had excellent working conditions and a number of bright students, there were two main reasons for his longing back to Norway: the general conditions at SU and his relations with his geological collegues in Sweden.

The financial conditions at SU had always been difficult, particularly because its economy to a large extent depended on the money given by the City of Stockholm. The city had no particular interest in natural science, and there was also a conflict between the Board of Trustees and the Faculty about the procedures for appointing professors and the financial basis of the professorships. The Faculty itself was also divided. In summary the very extence of SU was in danger.

Brögger operated in his own way and his scientific methods and problems differed much from those common at this time in Sweden. From the correspondence it is easy to see that the then young De Geer was a good friend, but the relations with e.g. Törnebohm and Högbom seem to have been strictly neutral. The relations with the Geological Survey of Sweden were not too good, as can be seen in letters from the pupils. For 
example Bäckström writes to Brögger from Heidelberg (April 2, 1891) that Rosenbusch had suggested that Bäckström should write to the Director of the Survey, Torell, and that Bäckström answered him »Torell does not like Brögger and his pupils».

It is therefore not surprising when Sederholm reported to Ramsay (Nov. 11, 1888) that Mrs. Brögger had remarked shortly after the death of Kjerulf that "Brögger had not looked so happy for a long time». However, before he was appointed in Oslo many problems had to be solved. His emissary in the Oslo faculty was Vogt. Brögger had two problems: his salary (he wanted the same as in Stockholm) and Helland, his main competitor.

\section{On Nov. 9, 1889 Vogt reports:}

»The matter of your professorship develops slowly but steadily and positively»

and

»Helland walks around like a 'roaring lion', both Bjerknes, Waage and G. O. Sars are afraid of him».

The Helland problem was solved by giving him a special chair in engineering geology.

In Stockholm and among his pupils it was no secret that Brögger wanted to return to Oslo. As usual in such situations dabbling in »)geopolitics» started about whom his successor would be. When Kjerulf died the question became acute. The problem was that the chair covered everything in geosciences. There was no obvious successor except Törnebohm, but he had according to rumours declined when Brögger asked him.

Ramsay seems to have been the candidate favored by the students, but it is of course difficult to show. He was genuinely interested but at the same time unsettled, because he wanted to return to Finland when Wiik retired and because he was afraid of trouble in Sweden because he was a foreigner.

It is also clear that Brögger in the beginning was supporting him. Early in 1890 (Feb. 14) Ramsay sent Brögger a letter in which he stated his conditions for accepting a professorship in
Stockholm. Brögger answered on March 6 in a frank letter (and honest as can be seen in hindsight). He says that the poor economy of SU has resulted in two things: there will be no permanent position, only a temporary one, and the salary will probably be halved or even a lesser fraction of his. He also points out that SU gives no degrees, therefore Uppsala University, which most likely will invest in its geology department in the future will attract the students. He then wrote:

"And still more important is the objection, I now make; a geologist is more than any other scientist a child of his native country. I know it from my own experience and have [therefore] the right to talk about it; you will also come to feel the same way. You have in Finland an excellent field for work, where there is much to do, and where you, with your intelligence and knowledge, will be able to accomplish much. Here you would have to break new ground in certainly not as rich a field of study, and you would as a scientist feel yourself unutterably more isolated in all the obdurate geological stupidity and ignorance that are accumulated here than in Finland, where you at least have a collegue with whom you fully can sympathize and cooperate.

You yourself have said that you would hardly be free from criticism and disagreeable experiences, if you as a foreigner were prefered before the numerous dilettantes who exist here and who seek the position in whatever form, and in this I think you are right.

I myself have not for a moment during the 8 years I have been here, been allowed to be unaware of that I am an encroaching foreigner, confidentially I can say to you as a friend that I with all my heart long to get away from here - and this feeling I assume that you yourself also will get very soon.»

On March 23, 1890 Ramsay answered Brögger that he had given up the thoughts about the chair in Stockholm. This was, however, in no way the end of Ramsay's interest for the Stockholm position. He seems to have suspected Brögger's intentions and he wrote Sederholm on Aug. 10,1890 that he was displeased, because his mother had visited Sweden and met a cousin to her, who was a member of the Board of Trustees. $\mathrm{He}$ had told her that Brögger had supported Ramsay and that the Board was positive. However, later Brögger had told them that Ramsay had declined because he did not want to break off his career in Helsinki, at least not on the conditions offered in Stockholm. Ramsay comments: »well, I wrote so in my letter, but you know, I think, how it originated.» 
Later in the letter he was grudging to Bäckström, whom he did not like very much. However this state of mind changed and in March 1891 he expressed in a letter to Brögger his statisfaction of not being mixed up in all the troubles.

Almost at the same time the question was temporarily decided. But it was certainly not an ideal position, if Flink's description has any truth (letter to Ramsay April 17, 1891):

»[Bäckström] is for the time being in Heidelberg drinking beer. The fact that he was not appointed the successor of Brögger grieved him so sorely that he immediately shook the dust of the ungrateful fatherland off his feet. Högbom is now, as you probably have heard, the Supreme Being in the Department. The rest you can certainly imagine. During the later part of Brögger's regime there was calmness, now it is death calm. Högbom is lecturing geology for some female elementary-school teachers, who, however, change for each lecture. It is totally useless work.»

There is no doubt that Ramsay was suspicious for a period of time about the Swedish geologists after these experiences, but his suspicions were probably not founded. His reactions are illustrated in an amusing way in a letter (Dec. 16, 1892) he wrote to Sederholm and which is indirectly referred to in the biography of Ramsay (Sederholm 1928):

»Visited Geological Survey of Sweden ... Since the Geological Society had had its meeting already on Thursday last week, I showed my map and the photographs [from the Kola Peninsula] privately for De Geer, Högbom, Svenonius, Hamberg, Toroddsen [sic] etc. and gave a talk. But I should not have done it, because it turned my stomach to see their reactions. With the exception of Toroddsen [the Icelandic volcanologist] and to some extent De Geer, nobody listened attentively, but all of them started immediately to interpret the photographs for me, you know rougly in the same way that Swedes can explain our Finnish political situation for us better than we ourselves can. Everybody had seen something similar or something still better in Halland, Scania, Grythult or Jokmok [sic] and whatever I am going to write about my ideas, these Swedes will probably imagine that they have pointed it out to me.

I was somewhat annoyed with them, thought that they otherwise were somewhat stiff, because they think that I was there in order to angle for the position at Stockholm University. Perhaps I misjudge them nevertheless, since some days later I was invited to Fenix [restaurant] for a light supper by De Geer, Hamberg, Högbom, Petersson, Svenonius, Gunnar Andersson, Jönsson. - Högbom is, to be sure, now a petrographer [he had been with Zirkel some time], as are Otto Nordenskjöld in Uppsala and several students. But I thought they carry on their petrography somewhat like amateur photography. In the same way as it is possible to learn to make photographies without a knowledge of physics and chemistry, so these gentlemen do petrography; that is, they recognize minerals and observe diverse structures without any real knowledge in optics or crystallography. Nordenskjöld, for example had on the latest meeting of the geological society gained much credit by discovering extrusive rocks in the Precambrian, that is some helleflintes with a glassy matrix, spherolites etc. This man I found ignorant of crystal optics.»

To some extent this is a sign of bad temper, for example Hamberg was certainly not ignorant because he applied for example Fedorov's methods already in the 90's. But he is also partly right because the late Per Geijer long ago told me that when he studied in Uppsala under Högbom $( \pm 1908)$ they recognized minerals in thin sections like acquaintances, they did not determine them. This technique was reintroduced by a new generation going to Rosenbusch (Sundius, Quensel and others). I also think that Ramsay touches upon a "national weakness» in Sweden.

Brögger had not only been careful to demand a higher salary than usual for coming back to Norway, but he had also obtained an agreement with the Director of the Geological Survey of Norway, Reusch, to have considerable amounts of money for field work in Norway.

As noted in the letter by Sederholm in 1896 (p. 33) life in Norway was not always a bed of roses for Brögger. The time in Stockholm therefore did appear increasingly happier, particularly since some of his former students were scientifically very successful. As an old man he appears to have only happy memories. In 1933 (Jan. 1) he wrote to Sederholm:

». . . he [Hedin] and you are about the only ones of those who worked with me at Stockholm University who still freshen my memories of the happy years of my youth in Stockholm.»

In a way they must have been happy, in the sense that in Stockholm he produced his major work and, besides V. M. Goldschmidt, it was there he had his most famous students.

Högbom left Stockholm after a few years, later he described them as depressing (Franzén 1971-73), a judgement certainly based on the internal and external squabbling going on in SU during this period of time. 


\section{Alkaline rocks}

At the end of the last century and in the beginning of this, alkaline rocks were eagerly studied by petrographers all over the world, because these rocks showed great variation and because it appeared that they should give valuable clues about the processes of differentiation.

Brögger himself was one of the main protagonists, studying the Oslo field. It is natural that his students should become interested in these rocks, but it is surprising how great their contributions were.

Ussing made several trips to Greenland and his research of some of the alkaline rocks of Greenland is classic. His premature death probably stopped further work by him there. It may be mentioned that Lorenzen and Flink also made early important mineralogical contributions to the alkaline rocks of Greenland.

Ramsay in 1887 happened to participate as a geologist on a Finnish expedition to the Kola Peninsula, which then was geologically almost unknown. He brought back rocks from mountains he hardly had time to visit. From letters to Brögger it appears that it was during the winter of 1888-89 in Heidelberg that he realized that his 'syenites' and 'diabase dikes' were alkaline rocks.

He then made a number of expeditions to these now world-famous areas. It is interesting to see that his first choice as a co-participant of his first own expedition in 1891 was a friend from the Stockholm group, Flink (letter to Brögger Oct. 24, 1890). In the letter he described how good the Ramsay-Flink combination would be, but that Flink needed money because he had a family to support. His dislike for Bäckström is also demonstrated in this letter because he described, probably correctly, how badly Bäckström was fitted for field work in uninhabited areas. In a later letter (March 13, 1891) he told Brögger that Hackman from Finland would participate, as we know a happy solution. Ramsay also studied the alkaline rocks at Kuusamo in Finland.
In Sweden none of Brögger's students studied alkaline rocks, but it was close. In a letter Bäckström (Aug. 4, 1891) informed Brögger that Rosenbusch had suggested to him to take up a study of the alkaline rocks of Särna, which had been located by Törnebohm in 1882 . Bäckström was not enhusiastic, perhaps for the reasons Ramsay mentions.

It is amusing to remember that the remarkable carbonatite, Alnön, was described in 1894 by Högbom, that is during his years in Stockholm. In his autobiographic notes Högbom remarks with his typical combination of confidence and diffidence:

"my paper about it [Alnön] is probably the Swedish petrographic paper which has aroused the greatest international interest. This is more likely a merit of the area than of the author.»

\section{Geology in the letters of the young Sederholm to Brögger and Ramsay}

From the correspondence of the Stockholm group the letters of Sederholm are the most interesting. It is possible to follow his scientific development during his early years. The letters show his general intelligence, his scientific imagination and that trait of egocentricity seemingly necessary for success. He was interested not only in his own field work but also in general geological questions with respect to Finland and the other Nordic countries.

The letter presented in Appendix 2, which was written already before the field season 1888 shows all these sides of his personality. The scientific problems of the Tammela map are formulated and he is puzzeled by the problems of the rapakivi granites.

In 1890 he was working on the Tammerfors (Tampere) map and on Aug. 19 he wrote to Brögger and told him that he suspected that the 'Archean' of Finland consists of two separate time divisions; on Oct. 3 he wrote that now he was convinced that he was right and that he could prove it. It appears that he was influenced by the 
divisions of the Precambrian made in North America.

In spring 1891 he defended his thesis about the Tammela area and Wiik acted as his opponent. Sederholm reported to Brögger (May 30) about Wiik's criticism (Wiik was an anti-uniformitarianist):

»Even Old Darwin came in for his share, as it always happens when Wiik gets excited and interested, 'I think, for my part, that both the author and Darwin are not right' as he put his somewhat oddly-composed sentence. The Professor [Brögger] can imagine that I felt quite elevated by being placed standing at Father Darwin's side in the prisoner's dock».

However, during the dinner after the thesis defence Wiik was kind and said:

»We have 'quarrelled' much both now and earlier, but it is the nature of geologists to quarrel much. Sometime we must come to terms, since both of us search for the truth and the truth is one».

Sederholm doubted that they reached unanimity before his death. In the same letter Sederholm also told Brögger about a visit to Munich where he met the famous paleontologist Zittel and remarked:

»Zittel, with whom I agreed upon that we should be able to find Archean fossils in Norden. - This summer I intend to spend some days really trying to find such fossils at a place where I think that they 'should' occur, since even the original layering (not by pressure) is preserved.»

As we know Sederholm could not fulfil his promise until 1899 when he found the Corycium enigmaticum, which has been so much discussed ever since.

Sederholm had not lived up to his reputation if the had not (in the same letter) used Brögger as an intermediary to promote his own and Finnish interests. Sederholm had been in Vienna and heard that a following congress should not be in Austria as planned. Anyway, according to his Austrian friends:

». . . the suggested site is Petersburg. If so, could it not be decided already on this congress [1891 in Washington, D.C.] that the following one should include an excursion to Finland at least for non-paleontologists or stratigraphers? We could show the Hogland [Island] (1 day), Helsingfors with dinner [paid by well-off] citizens and visit the Tammerfors area with its conglomerates, schists, gneisses, tuffs etc (with big discordance) (1 to 2 days) and possibly for some participants, in addition, rocks from Åland. This excursion could be quite interesting. Beautiful sceneries and hospitality we can surely count upon ... .

. . . Would it be possible for the Professor [Brögger], if there is an opportunity, to suggest something like this? If there is no decision made about the program, the Russians will probably make completely different arrangements.»)

As we see Sederholm had early planned for the excursion in 1897 which was not only geologically successful but also put the science of geology into the minds of ordinary people in Finland with the help of the scientist-journalist Guss Mattsson, who participated and wrote for a newspaper. Whether Brögger succeeded in Washington is not clear, because the 1894 congress was held in Zurich and Petersburg got the 1897 congress.

This is an example of Sederholm's strategic planning. Another is given in the letter in Appendix 2 where he discusses the future of the Survey already at the very beginning of his employment. His remarks about Moberg are frank, but he seems to have appreciated him and cooperated well with him. On Oct. 16, 1890 he wrote Brögger:

»Moberg has also as chief the great merit of never putting any obstacles in the way of anybody's work but, on the contrary, supports it in the best way.»

About this time a governmental committee had studied all kinds of cartographic work going on in Finland. Ramsay in a letter to Brögger (March 29, 1890) remarked that Moberg and Sederholm are working with changing and modernizing the geological mapping.

But Sederholm also has greater visions for Nordic geology. He wrote Brögger (March 1, 1891) from Heidelberg and Rosenbusch:

"More than ever I have recognized here how much the [Stockholm] University is my spiritual fatherland and more than ever have I here understood how natural it would be that the 'lead' of geology passed to Norden like it sometimes has been in other sciences. I only hope that you may find time and strength to go on working for this goal. Sometime also the Swedes must wake up and then the Nordic school with the enormous material it has will do beautiful things.»

Even if this was a moment of wishful dreams it shows his great ambitions. Sederholm did not 
only discuss his own geological problems but was also genuinely interested in the trends of his science. An example of this is in a letter to Brögger (Oct. 16, 1889):

"Generally I think that the mineralogists in a way are better favored than the geologists. Since, what is it we young have to do when once the epoch-making doctrines of the importance of the primary textures and regional metamorphism by pressure have been lucidly expressed and systematically established by the generation that is now at the forefront?

We probably have to work our whole life applying these doctrines on the material available, in the first hand the 'Archean', without really having any hope of finding something new of importance. It will be a golden age for the whole deluge of German graduate-student scientists, who come here in hosts in order to cut stone 'zur Erlangung der Doktorwürde' [in order to obtain a doctor's degree].

But in crystallography the conditions are different. I am certainly quite weak in this branch and for this reason possibly have the vague ideas of an amateur about this science, but it always seems to me as some new, important basic principle is to be discovered in the near future, some doctrine, which could revolutionize our whole concept of the crystal structure and perhaps of the nature of atoms and molecules.»

This letter is remarkable in two ways, on one hand his pessimism about the future of his own branch of geology, and total lack of intuition about his own future role as a pathfinder; on the other his intuitive insight into the forefront of science about three decades later. Of course, the idea of crystal structure was well known, but this was scarcely the case with the chemical thermodynamics of Gibbs. It was at this time only known and understood by a few persons in the whole world.

\section{Final remarks}

Brögger's students needed less and less of his help and advice when they grew in knowledge and experience. After his return to Oslo, he devoted himself to the development of the university there as well as the general affairs of science in Norway. As can be expected the correspondance between him and his pupils became more infrequent, finally consisting of congratulations to celebration days, information about visits to Norway or specific scientific questions.
What Brögger wrote to Ramsay (p. 35) about geologists and their native countries is to a high degree valid for himself. His geological problems were in the first hand Norwegian and only in the second hand general. The reason for his great international success was in my opinion not his original thinking but that he was the right man at the right moment at the right place with the right problem. Most of his pupils belonged to the same category, but less distinguished, the exception is Sederholm, who undoubtly had the real fertile scientific mind. Later in life in Oslo Brögger got another pupil with a taste for general problems: V. M. Goldschmidt.

J. H. L. Vogt is a difficult case, he is hardly a real pupil of Brögger, he is more of a collegue to him. Vogt's deep devotion to problems of ore geology and metallurgical processes made him interested in the general problems of geochemistry. I have a feeling that his importance as a scientist often is underestimated because he lived at the same time as the intensive science promotor Brögger. At this point it may be mentioned that in 1909 the newly graduated N. L. Bowen from Canada wrote to Oslo that he wanted to come for a year to study for Vogt and Brögger. He never went, but if, he and Goldschmidt had become fellow students!

A special position in the circle around Brögger has De Geer. He had studied in Uppsala and was employed by the Swedish Geological Survey when Brögger came to Stockholm. He was younger than Brögger but somewhat older than most of the students. It is evident from the correspondence that they found him $»$ the intelligent Swede». He became a close friend to many of them, including Brögger. As is wellknown De Geer was a pioneer in Quaternary research and strangely enough Brögger, Ramsay, Sederholm and Ussing in a way became his pupils. Brögger in the Oslo region, Ramsay and Sederholm in Finland and Ussing in Denmark.

Now, a century after Brögger's Stockholm period, it is easy to see the enormous importance it had on the future development of Nordic 
geology. This influence differed between the countries: in Denmark and Greenland the untimely deaths or Lorenzen and Ussing made the direct effect weaker, in Finland with Ramsay and Sederholm the effects were strong, in Norway geology was of course dominated by Brögger for a very long time.

Sweden is a strange case, the existence of other universities and the strong Geological Survey represented competitors. Swedish students could not obtain degrees at SU, they had to move to Lund or Uppsala, also there was little mutual respect between Brögger and the Survey director Torell. The Swedish pupils often ended up in prominent positions, but in different fields: Hamberg, at this time eminent crystallographer became professor of geography, and Bäckström changed from professor to businessman and politician. Hedin explorer and Lundbohm in-

\section{References}

Ahlmann, H. W:son, 1969-71. Hamberg, Axel. Svenskt biogr. lexikon 18, 78-81 (in Swedish).

Aminoff, G., 1932. Gustaf Flink. Geol. Fören. Stockholm Förh. 54, 233-240 (in Swedish).

-, 1934. Axel Hamberg. Kungl. Sv. Vetenskapsakad. Årsbok 1934, 265-272 (in Swedish).

Andersen, S. A., 1934. Ussing, Niels Viggo. Dansk biogr. lexikon 24, 587-589 (in Danish).

Bedoire, F. and Thullberg, P., 1978. Stockholms universitet 1878-1978. Stockholms universitet, Stockholm. 236 p. (in Swedish).

Bäckström, H., 1926. Hjalmar Lundbohm. Geol. Fören. Stockholm Förh., 48, 481-482 (in Swedish).

Bøggild, O. B., 1912-15. Niels Viggo Ussing. Dansk Geol. Foren. Medd. 4, 1-18. (in Danish).

Borgström, L. H., 1929. Wilhelm Ramsay. Minnesskrift. Sv. Tekn. Vetenskapsakad. Finland Förh. o. Medd. Nr 5,6. 26 p. (in Swedish).

Bring, G., 1933. Walfrid Petersson. Jernkont. Ann. 117, 171-177, (in Swedish).

Carstens, C. W., 1932. J. H. L. Vogts forskervirksomhet. Norsk Geol. Tidskr. 11, 440-466. (in Norwegian).

Det Norske Videnskaps-Akademi i Oslo, 1940. Ved W. C. Brøggers bortgang. Gravferd og minnemøte. Oslo. 106 p. (in Norwegian).

Elgenstierna, G. 1925. Cederström. Den introducerade svenska adelns ättartavlor 1, 821, Tab. 44. dustrialist. But his influence on the Stockholm department was felt for a very long time: even when I studied in the 1930's much of the department was arranged like it had been in Brögger's time half a century earlier.

However, the intellectual influence of Brögger in the Nordic countries is still felt in most geosciences from glaciology to paleontology and crystallography, even if the present practicians rarely are aware of their bonds with Brögger. He must have had a special gift to attract intelligent students and make them spellbound to his science.

Acknowledgements. I want to express my sincere thanks to all those who have helped me in various ways, too many to be mentioned. A particular thanks goes to Dr. Franciska Sundholm who is a grandchild of Wilhelm Ramsay and who has taken care of his large correspondence and allowed me to study it. Grants from Clara Lachmanns Fond, Letterstedtska Föreningen and Föreningen Norden are appreciated.
—, 1930. Paykull. Den introducerade svenska adelns ättartavlor 5, 637, Tab. 9.

Enkvist, T., 1972. The history of chemistry in Finland 1828-1918. Soc. Sci. Fennica. Helsinki, 161 p.

Eskola, P., 1967. Outline of Sederholm's life and work. In Sederholm J. J. Selected works. Granites and migmatites. Oliver \& Boyd, Edinburgh. 577-587.

Foslie, S., 1932. Nogen minneord om professor J. H. L. Vogt. Norsk Geol. Tidskr. 11, 437-439 (in Norwegian).

Franzén, O., 1971-73. Högbom, Arvid Gustaf. Svenskt biogr. lexikon 19, 664-667 (in Swedish).

Geijer, P., 1927. Hjalmar Lundbohm. Minnesteckning. Geol. Fören. Stockholm Förh. 49, 273-289 (in Swedish).

Hackman, V., 1935. Jakob Johannes Sederholm. Biographic notes and bibliography. Comm. géol. Finlande Bull. 112. $29 \mathrm{p}$.

Hamberg, A., 1928. Fredrik Vilhelm Svenonius. Geol. Fören. Stockholm Förh. 50, 303-305 (in Swedish).

Hausen, H., 1968. The history of geology and mineralogy in Finland 1828-1918. Soc. Sci. Fennica. Helsinki, $147 \mathrm{p}$.

Högbom, A. G., 1895. Gustaf Nordenskiöld. Geol. Fören. Stockholm Förh. 17, 639-642 (in Swedish).

-, 1927. Helge Mattias Bäckström. Svenskt biogr. lexikon, 7, 110-114 (in Swedish).

Hoppe, G., 1981. Axel Hamberg. Minnesteckning. Levnadsteckn. Kgl. Vet. Akad. ledamöter 183. Stockholm 27 p. (in Swedish).

Nachmanson, E., 1928. Förteckning över Göteborgs Kungl. 
Vetenskaps- och Vitterhets-Samhälles ledamöter 1774-1927. KVVS Handl. (4) 32:2, 53.

Quensel, P., 1933. Helge Bäckström. In memoriam. Geol. Fören. Stockholm Förh. 55, 423-428 (in Swedish).

-, 1933. K. F. Johansson. Geol. Fören. Stockholm Förh. 55,431 (in Swedish).

—, 1933. Carl Morton. Geol. Fören. Stockholm Förh. 55, 432 (in Swedish).

-, 1940. W. C. Brögger och Stockholms Högskolas mineralogiska institution. Geol. Fören. Stockholm Förh. 62, 112-120.

Schetelig, J., 1925. Brøgger, Waldemar Christofer. Norsk biogr. leksikon 2, 299-314. (in Norwegian).

Sederholm, J. J., 1928. Wilhelm Ramsay. Minnestal vid Finska Vetenskaps-societetens årshögtid den 29 april 1928. Soc. Sci. Fennica. Årsbok 6B:6. 27 p. (in Swedish).

—, 1967. Selected works. Granites and migmatites. Oliver \& Boyd, Edinburgh, 608 p.

Strand, T., 1977. Vogt, Johan Herman Lie. Norsk biogr. leksikon 18, 143-145 (in Norwegian).

Thomasson, C.-G., 1969. Stockholms högskola 1878-1887. Matrikelbiografier. p. 37 (in Swedish).

Wegmann, E., 1975. Sederholm, Johannes Jakob. Dict. Sci. Biogr. 12, 271-275. Scribners, New York.

\section{Appendix 1. Biographic notes of Brögger's students and some other persons.}

Bäckström, Helge (1865-1932), Ph.D. 1891, teacher of mineralogy and petrography SU 1891, professor SU 1908-1914 (Högbom 1927, Quensel 1933).

Cederström, Anders (1865-1921), fil.lic. 1892, tenant of an entailed estate from 1894 (Elgenstierna 1925).

De Geer, Gerard (1858-1943), fil.kand 1879, professor SU 1897-1924. Major figure on Quaternary geology.

Eichstädt, Fredrik (1855-1910), fil.dr. 1882, teacher of chemistry, mineralogy and geognosy, Chalmer's Institute of Technology, Gothenburg 1889-1910 (Nachmanson 1928).

Flink, Gustaf (1849-1932), primary school teacher 1871, Swedish Museum Natural History 1906-1916 (Aminoff 1932, Zenzén 1944).

Hamberg, Axel (1863-1933), fil.dr. 1901, professor of geography, Uppsala university 1907-1928 (Aminoff 1934, Ahlmann 1969-71, Hoppe 1981).

Hedin, Sven (1865-1952), Ph.D. 1892. World-famous explorer in Asia 1885-1935 (Wennerholm 1980).

Högbom, Arvid Gustaf (1857-1940), fil.dr. 1885, teacher of geology and mineralogy SU 1891-1894, professor SU 1895-96, and Uppsala University 1896-1922 (Franzén 1971-73).

Johansson, Karl Fredrik (1866-1933), mining engineer 1891, international consulting mining engineer ca 1900-1922 (Quensel 1933, Zenzén 1948).
Wennerholm, E., 1980. Sven Hedin. En biografi. Bonniers, Stockholm, 304 p. (in Swedish).

Zenzén, N., 1944. Flink Gustaf. Svenska män o. kvinnor 2, 534 (in Swedish).

-, 1948. Johansson, Karl Fredrik. Svenska män o. kvinnor 4, 89 (in Swedish).

-, 1954. Svenonius Fredrik Vilhelm. Svenska män o. kvinnor, 7, 382-383 (in Swedish).

\section{Letters}

can be found in the following libraries, if they were received by:

Brögger: University Library, Oslo University, Oslo, Norway Högbom (autobiography): University Library, Stockholm University, Stockholm, Sweden.

Ramsay: Dr. Franciska Sundholm, Department of Chemistry, Helsinki University, Helsinki, Finland.

Sederholm: University Library, Ảbo Academy, Turku, Finland.

Ussing: The Royal Library, Copenhagen, Denmark.

Vogt: University Library, Norwegian Institute of Technology, Trondheim, Norway.

Lorenzen, Johannes (1855-1884), cand.polyt. 1877, Mineralogical Museum, Copenhagen 1878-1884. Died on passage to Greenland.

Lundbohm, Hjalmar (1855-1926), chemical engineer 1877, Geol. Survey of Sweden 1885-1902. In charge of founding the community and mines of Kiruna 18981920, known as the »Kiruna King» (Bäckström 1926, Geijer 1927).

Moberg, Karl Adolf (1840-1901), fil.mag. (chemistry), Geol. Survey of Finland 1878-1893 (Hausen 1968).

Morton, Carl (1860 - 1933), studied at SU 1884-1890, consulting geologist (Quensel 1933, Thomasson 1969).

Nordenskiöld, Gustaf (1868-1895), studied at SU 1887-1895. Extensive travels because of tuberculosis, wrote about cliff dwellers in Mesa Verde in 1893 (Högbom 1895).

Paijkull, Gunnar (1866-1935), studied at SU 1883-1887, authorized public analytical chemist (Elgenstierna 1930).

Petersson, Walfrid (1862-1933), fil.dr. 1890, professor of mining, Royal Institute of Technology, Stockholm 1901-1927 (Bring 1933).

Ramsay, Wilhelm (1865-1928), fil.lic. 1888, professor of mineralogy and geology, Helsinki University 1899-1928 (Sederholm 1928, Borgström 1929).

Sederholm, Jakob Johannes (1863-1934), fil.lic. 1892, Geol. Survey of Finland 1888-1933, director 1893-1933. Special volume with his works (Sederholm 1967) (Hackman 1935, Eskola 1967, Wegmann 1975).

Svenonius, Fredrik (1852-1928), fil.dr. 1880, Geol. Survey of Sweden 1881-1917 (Hamberg 1928, Zenzén 1954). 
Ussing, Viggo (1864-1911), Ph.D. 1893, professor of mineralogy and geology, Copenhagen University 1895-1911 (Böggild 1912-15, Andersen 1943).

Vogt, Johan Herman Lie (1858-1932), studied mining and metallurgy 1876-1885 in Norway and abroad, professor of metallurgy, Oslo University 1886-1912, and of

\section{Appendix 2. Letter by Sederholm to Brögger}

Helsingfors May 27, 1888

\section{Dear Professor:}

Now have been at home for a while and to some extent become used to the, in several respects, changed conditions, my thoughts naturally turn back to the [Stockholm] University, where I spent the previous term and therefore I use this opportunity to thank the Professor [Brögger] for his kidness and for all his efforts. This term was the first one when after periods of enforced rest, I could get back into the work again - for how long I don't know. However, I hope that I now have a firm but, owing to the short time, somewhat imperfect base for my further studies. Before now I always experienced a sense of shame at my ignorance which seemed to me still greater because I did not even know where I could turn to find information in each special problem.

Now I think that I have at least obtained a general view of the whole [matter] and even had my eyes opened for the new which must be accomplished. Even if, in the future, I find an opportunity to study under other teachers, I shall naturally always feel myself as the Professor's pupil, because it is from your school of thought $I$ have come and in which I am going to work in the future.

This summer I shall have almost too many possibilities of testing my abilities. The quadrangle map Tammela, which I have definitely taken over, seems to present a good deal more than I found in the part I studied last summer. I hope to be able to draw some conclusions about the original thickness of the schist formation. - The uralite porphyrites are still more transformed in some places than in Hattula. They partly become real fibrous schists, however with well preserved uralite crystals. - The abundant pegmatite in Tammela, where among other things tantalite has been found, is surrounded by a large area of tourmaline-bearing granite. The boundary is formed by a rock designated as »scaly gneiss», but I have seen no samples of it. Possibly it may be some kind of greisen. - Amongst many other things.

I have also seen samples of several rocks from Alland. The rapakivi-related granite occurs in a multitude of peculiar structural modifications, e.g. one with quite small well crystallized quartz dihedrons occur squeezed between the rather large orthoclase crystals. In addition numerous other transitions between granite porphyry and microgranite porphyry occur, naturally also granophyre. Even with the naked eye and still better with a magnifying glass, one can observe in some samples a superb granophyric structure. The multitude of structural varieties is on the whole surprising geology, ore geology and non-ferrous metallurgy, Norwegian Institute of Technology, Trondheim 1912-1929 (Carstens 1932, Foslie 1932, Strand 1977).

Wiik, Johan Fredrik (1839-1909), professor of mineralogy and geology, Helsingfors University (Hausen 1968).

and they are as fresh as they occur in glacially worked shore cliffs.

Does the Professor want to have good samples of the granites I collect here this summer in exchange for your permission to let me borrow thin sections made of them? If so, I could already at the end of July send samples to the University, if only I have a definite promise to have some tens of sections made before end of September. I shall return them as soon as I have examined them. I think that it is not often one can find so fresh and so diversified samples of these [rocks]. Naturally I will send specimens to the University anyway, but they would be not quite so numerous in that case.

All the better assistents have specifically asked to come with me this summer. I am afraid that they will stream back to Gylling next year because I expect strict reliability and diligence. Anyway it will be difficult to have time to supervise everything they do. Now to be true I get only 3 or 4 men, but in ordinary years, there are even 5 .

I have already succeeded in arranging the work with the quadrangle maps and their descriptions just as I wanted. I am allowed to use as much time as I need for the interpretation of the Tammela map, and also, next winter, I will be allowed to leave the Aland map completely, if I find no time for it. However, I hope to be able to finish at least the major part of the work.

Moreover I have got a promise that next year I can start on the Tammerfors [Tampere] map, where the schist formation occurs in the greatest variety. Already this fall my assistents may have time to map a small portion of it.

So far everything is well. On the other hand the outlook for having enough money for thin sections etc. is gloomy. The sum set aside for extra expenses is absurdly small compared to what the research costs. I think it is 500 [Finnish] marks. And without strong lobbying the Senate will give no special appropiation for instruments, thin sections, books etc., which are so necessary to us. In this respect I think it would be of particularly good effect if the Professor would, in full detail, point out to Moberg how impossible it is to study rocks only with the help of our badly constructed eyes and how a petrographic department must be organized in order to be adequate to this purpose. I mean that he, if he asks for an extra appropiation, probably will base his request on the Professor's letter, and if then something is missing he will think that it is unnecessary. I believe that it is not an absolute impossibility that the Senate could appropiate an extra sum for the purchase of the most indispensible equipment, if only the request has enough authority. Above everything a comparison with the conditions in Stockholm and foreign countries is probably of great effect. 
Since our whole Survey is established solely on the basis that we must not be inferior to others, because no need for it existed, I hope, even in this case, the authorities should try not to be behind the times too much.

What I otherwise cannot obtain, I shall naturally buy by private means, but it would be better if the Survey could pay the most necessary [items]. It would be much better to have a few bad assistents less than having no money for research.

All personal matters I think I can arrange with Moberg, because he is not difficult to come to terms with. However, right now he appears to be slightly afraid that I shall become too bothersome and headstrong, if he does not protect his dignity. Anyway I am sure that we are going to cooperate perfectly and that I shall be allowed to arrange my own work roughly as I like.

But it is more difficult to change the Survey in its entirety to its true purpose. What I am saying has naturally not the slightest importance for the men in authority, since I, because of my youth and lack of any kind of scholary tests of a higher kind than the bachelor's diploma, have not the remotest kind of authority. - - No matter how impossible it will be to publish tolerably usefull maps according to the old plan and based on the tremendously bad base maps we have, I nevertheless think that it would be very difficult to have those concerned to try a new plan or, preferably, to understand that the old one is useless.

Although the topographic [features] are almost the most important, they are shown in a quite condensed form and are often so distorted that places are plotted 1 to $2 \mathrm{~km}$ from their real positions. But as long as we have them it is nevertheless possible to present something each year and at least make a show of doing some geology or, as the phrase goes 'preliminary work', without more than a crumb of geologic science in it. Routine is convenient, but [if] in contrast one is going to publish general maps and detailed work, they must have a real value, and be evaluated no longer by engineers, senators, agriculturists and other good folk, but by scientists.

Then there is a matter which I long ago discussed with Wiik and only today heard repeated by Gylling. The maps must be 'petrographic', not geologic, it is said. Wiik even declared that such investigations cannot be scientific but only preparatory. Otherwise the work becomes purely subjective, he said, he who always is talking about the qualities of the deductive method and is so thoroughly subjective himself.

By a petrographic map is meant here one in which the rocks for arbitrary reasons are assigned certain arbitrarly designations without any consideration of genetic relationships and such. And as long as we not even have established the relations of the most common rock types to each other and elucidated their genesis, it will continue mostly in the same way and no unity will be reached in the nomenclature.

Moreover it is a doctrine that the maps too must have 'practical value' what, of course, is as it should be when 36000 marks are taken from the poor Finnish crofters to perform this highly necessary work. Now perhaps people believe that ores cannot be prospected on a scientific basis and that the less methodical the approach gives the more success. However, nobody could probably assert that farmers or such fellows can have least use of maps on such a' small scale, however splendid they may be - except possibly as a wall decoration in the study of an educated farmer.

The whole plan is thus in reality a failure, especially because it is planned for detailed maps but the purpose is nevertheless said to be to produce a general map. The result is a compromise which is neither the one nor the other. Of course, with good intentions it is possible to produce a good deal of good results according to this plan, but it will be, so to speak, beside its purpose.

All the same, it would not be desirable to change it now, except possibly for a trial. It is better to do it at once, when the proper time comes, if it does come sometime. Furthermore these changes would need considerable time and efforts and there is nobody here who has them in excess. But some day at least this question will be seriously raised and, if it does not succeed then, I will lead my sheep to another market.

At present my main point is not to scare Moberg so that he retires within a few years. But in the first place his talk about retirement is not made in full earnest, and secondly [the Government] is unwilling to lose him because in that case he has the right to 4000 marks per year for his earlier job in the abolished Mining Board.

For the present Gylling can therefore lick his lips, although he already last summer confided to one of his helpers that he soon would get a higher official position. Nobody seems to care too much about him, while, on the other hand, Ramsay has a great deal of attention paid to him. However, for the present I think that in the case of a sudden change Gylling would have rather definite prospects. If so, I will use all my powers as intriguer to promote Ramsay, since personally I have not the slightest chance and here it is not a question of person but of matter. Ramsay and I have almost from the moment we became fellow-students, formed a defensive and offensive alliance.

We hope much by the Professor's help in our endeavors. My hope is that you will play the role of a 'deus ex machina' who at the right moment intervenes and ordains everything in the best way. The Professor will notice that I am an awfully tough intriguer, but this is the inevitable result of the conditions of our faction here. In addition nothing is accomplished if not every effort is made to present the case. Otherwise no 'roast sparrows fly into one's mouth' [refers to the Medivival German fairy tale 'Schlaraffenland'].

But, if we can count on the Professor's help, which, I dare say that you will be so kind and give us, the very case is based on one fact, which it may seem indiscreet for me to touch upon, that is to say that no catastrophy has happened to your health before then. I have several times had the intention of touching upon the matter which I have had on my mind since long but which I have never been able to put into words.

Even now I do it with much hesitation, particularly since I fear that I present it somewhat abruptly. We, Finns, have not the capability of expressing our thoughts and words so malleably and beautifully as the Swedes do but think and act more straightforwardly. Therefore I go straight to the point and tell you frankly that you will soon go the way of v. Lasaulx and Schuster and many others if you go on overworking yourself as you do. This is not only my own opinion that I express but I have heard several others say about the same. 
I have seen too much of the misery to which overwork leads to have a frightened panic over this sort of thing, but I think that I have also seen several examples of how far nature can be streched in this manner before it gives way and hence that I am not addicted to exaggeration. But nevertheless I am firmly convinced that you will fall pretty soon if you go on like now without ever letting your brain lie fallow, preferentially some months. If there would be an end to, or at least some halt in, the strain under which the Professor works, a happy end could be thought of. But we, your pupils, know that the work, which you have made up your mind to accomplish in the immediate future and which is lying waiting for you and is harassing you, is so enormous that a person with the greatest capacity for work scarcely could finish it in ten years. Therefore it is unbelievable that eventually you will not be broken under this burden. If, hopefully, you had the ability to relax, there would be no danger, but your energy keeps you going and squeezes out the last drop of your powers.

I, myself, got almost a headache when I listened to your lecture at the latest meeting of the Geological Society [in Stockholm] and saw how your brain worked with the last nourishment it could pinch.

Well, now I have said it and you are quite welcome to get angry with me about it, if you only believe at least a little of what I have said. I am definitely aware of the risks I take by using such a candid language, and it may also appear foolish to believe that I, by my words, can influence the matter. But I wanted at least to say my frank opinion to the Professor. I think that we have a certain right to expect that you take care of your health, [because] of the position you have and still more will have when your system has been finished. Even with this [system] we can gladly wait some time before it is published, because we know well, in any case, that nobody at present has the necessary qualifications to do the same. Most of them have their national one-sided views or also not the necessary knowledge.

But when once you have finished it and published it, it will only be necessary for you to sketch the whole in general outline. Detailed investigations you can leave to others and allow yourself a sorely needed rest. Certainly there are enough people who can work out the finer details of the proofs. Then you have in any case [already] in advance forced them to be your pupils or otherwise present erroneous opinions. Any careful, diligent and honest fellow can describe the pneumatolytic transformations of gabbro or Norwegian granophyres and granulites, if he only knows what he has to do and how he has to make the observations. No doubt, your powers will still be more than needed.

Once again I beg the Professor that he may not believe that I am impertinent when I say all this, and not even let it leave the impression that I am well-meaning but really awkward, because, in any case, I have wanted to do the best that can be done.

When you write to Moberg I hope to get an answer about the samples of the Åland rocks.

My kind regard to Mme. Professor

The Professor's respectful servant,

Johannes Sederholm 